LJUBOMIR JEVTOVIĆ

Institute of Archaeology

Belgrade, Serbia

E-mail: jevtoviclj@gmail.com

IVAN BOGDANOVIĆ

Institute of Archaeology

Belgrade, Serbia

E-mail: leshicka@gmail.com

ŽELJKO JOVANOVIĆ

Center for New Technology

Belgrade, Serbia

E-mail: nichegoo@gmail.com
Received: November $12^{\text {th }} 2020$

Accepted: December $10^{\text {th }} 2020$

Original research article

904:725.826"652"(497.11)

902.6:528.7(497.11)

COBISS.SR-ID 29186825

https://doi.org/10.18485/arhe_apn.2020.16.4

\title{
IMAGES OF THE AMPHITHEATRE - USE OF PHOTOGRAMMETRY IN EXCAVATIONS OF THE VIMINACIUM AMPHITHEATRE
}

\begin{abstract}
Photogrammetry is the science and technology of obtaining information about physical objects and the environment using $2 D$ photographs. Recent technological advancements allowed the method to become accessible and quite valuable in the studies of cultural heritage. The method was introduced into the field procedures of archaeological research of Viminacium in 2012. The goal of this paper is to demonstrate the usage of photogrammetry during investigations of the amphitheatre and to exemplify its applicability and benefits for future archaeological excavations. Based on our experience, the method proved to be easy to use and incorporate into existing procedures, especially as it was significantly faster and economical compared to the traditional documenting techniques. Obtained $3 D$ models can fulfill various needs, from the creation of regular archaeological documentation to the visualization and presentation of the results of research.
\end{abstract}

KEYWORDS: VIMINACIUM, AMPHITHEATRE, PHOTOGRAMMETRY, 3D MODELING, FIELD METHODS.

\section{INTRODUCTION}

Archaeological excavations are a destructive process, so it is a researcher's obligation to document excavated features in the best possible way. Traditional methods require precise mapping of units, either by taking hand measurements or with the use of specialized tools - a theodolite, total station, or laser scanners. These standard measuring methods are both time and financially consuming, which presents a problem, since the pace of excavation often requires fast, precise, and economical recording of a vast number of features. The development of new technologies used in photogrammetry has allowed the creation of high-resolution 3D documentation which can be used during excavations for analysis of artefacts, or mapping of remains in the landscape. This method was used during recent excavations on the amphitheatre of Viminacium. Both aerial and terrestrial photogrammetry were used for the creation of highly detailed standard 2D technical documentation, and also digital 3D reconstructions of the excavated structures and features. Immediately, photogrammetry 
became a standard documenting technique, which gradually replaced older traditional ways of recording features. The purpose of this paper is to exemplify our experience with the method, its benefits and its faults, as well as its potential application.

\section{PHOTOGRAMMETRY IN ARCHAEOLOGY}

Photogrammetry ${ }^{l}$ is an art, science and technology of obtaining reliable information about physical objects and the environment through the process of recording, measuring and interpreting photographic images and patterns of recorded radiant electromagnetic energy and other phenomena (Aber, Marzolff, Ries 2010: 23).

The beginnings of photogrammetry can be traced to the middle of the $19^{\text {th }}$ century. Throughout the last century it saw many advancements ( $c f$. Wallace 2016: 16-25; Schenk 2005: 7-9; Kraus 2007: 3-9), but, albeit it being useful, until recently its application in archaeology was rather limited. ${ }^{2}$ This was mainly due to the complex (mechanical and optical) processing procedures. The advent of digital photography, the development of higher capacity storage devices, increase in computational power (Douglass, Lin, Chodoronek 2015: 138) and the improvement of analytical methods, based on computer solving of mathematical algorithms, facilitated the significant leap in advancement and application of this technique. So, it evolved from being a completely analog, optical-mechanical tool, to digital photogrammetry (softcopy), based on the digital images and computer vision (Aber, Marzolff, Ries 2010: 23).

The basic principle of modern, digital photogrammetry is the analysis of $2 \mathrm{D}$ photographic recordings for the purpose of creating a $3 \mathrm{D}$ reconstruction of an object or terrain in a digital or graphical form (Luhmann et al. 2011: 2). The

1 General literature regarding photogrammetry $c f$. Linder 2003; Linder 2009; McGlone et al. 2004.

2 For various types and applications of photogrammetry cf. Luhmann et al. 2011: 4-6; Kraus 2007: 2. reconstruction can be used for obtaining precise data and measurements, such as quantification of distances, heights, areas and volume, or for the creation of topographical maps, digital elevation models (DEM) and orthography (Aber, Marzolff, Ries 2010: 23).

Recent hardware and software developments facilitated the accessibility of this method. Most significant were the inventions of stronger processors and graphic cards, in combination with modern digital photography processing software with automatic procedures for determining the spatial orientation and the overlapping of images. These advancements enabled a fast, simple, and direct way of obtaining the results, without requiring detailed knowledge about the technical aspects of the method (Verhoeven, Docter 2013).

Usage of photogrammetry significantly simplified recording of the features and increased the speed of archaeological excavations. Its potential, benefits and wide application were proven in numerous examples, so in recent years it has become an unavoidable part of the excavation process.

In the recent period, the mentioned method has been added to archaeological practice in Serbia. Stereo-photogrammetry was used on the sites Caričin Grad and Gamzigrad in the last two decades of the $20^{\text {th }}$ century (Иванишевић, Бугарски, Булатовић 2015: 55), while a stereoscopic analysis of orthographic images of the archaeological site Viminacium was done in the early $21^{\text {st }}$ century (Korać, Pavlović, Mrđić 2006). The first modern, digital photogrammetric recording was conducted in 2003, during underwater excavations of the remains of Trajan's bridge on the Danube (Karović, Mihajlović, Vučković 2008). The interest in this method re-intensified in recent times. In 2012 it became a standard documentation technique on Viminacium $^{3}$ and in 2014 it was introduced to the

3 The usage of the photogrammetric method in the archaeological excavations of Viminacium was presented by Ž. Jovanović during the annual meeting of the Archaeological institute „Arheologija u Srbiji 2012-2013, pregled istraživanja", held in Viminacium on the $27^{\text {th }}$ of November 2013. 


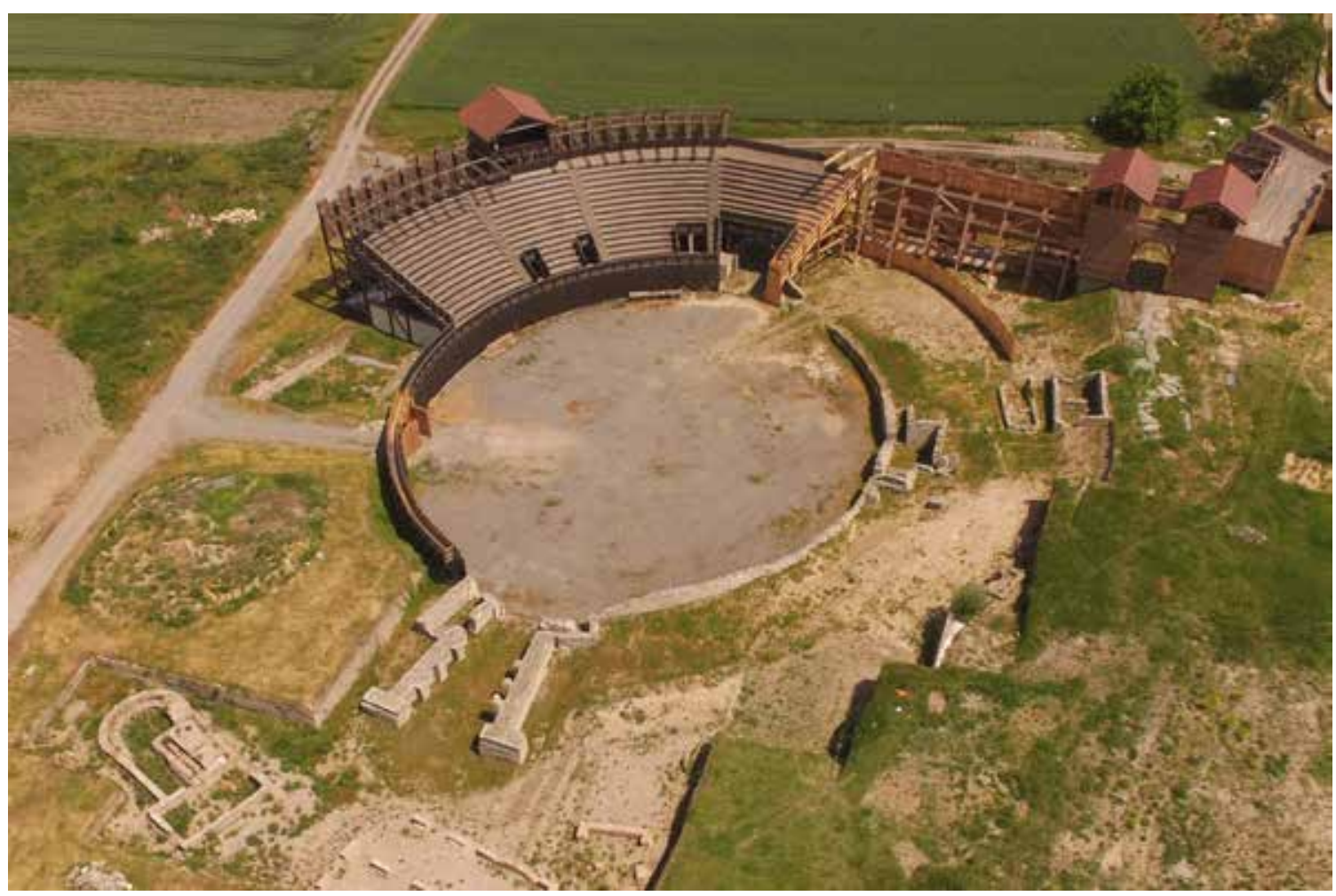

Fig. 1 The Viminacium amphitheatre (documentation of the Institute of Archaeology, Belgrade).

excavations of Caričin Grad. Since then, the use of photogrammetry became widespread on the other sites in Serbia. ${ }^{4}$ The application of these techniques set a new standard in the documentation, presentation and visualization of our cultural heritage (Иванишевић, Бугарски, 2015; Иванишевић, Стаменковић, Јовановић 2017).

\section{PHOTOGRAMMETRIC IMAGING OF THE AMPHITHEATRE OF VIMINACIUM}

The Viminacium amphitheatre is located in the northeastern corner of the city, $60 \mathrm{~m}$ away from

\footnotetext{
4 The most notable example is the project ArchaeoLandscapes Europe that resulted from the cooperation between the Institute of Archaeology from Belgrade, the Ludwig Boltzmann Institute from Vienna, the Austrian Academy of Sciences and Römisch-Germanisches Zentralmuseum from Mainz. The program involved photogrammetric imaging of sites on the Danube bank and sites in the Southern Serbia and the Raška region (Бугарски, Иванишевић 2014).
}

the northwestern corner of the legionary fortress. The archaeological excavations of the amphitheatre started in 2007 and they lasted until 2017 (Nikolić, Bogdanović 2015; Богдановић, Рогић, Вуковић-Богдановић 2018). During the mentioned period, almost the whole building was unearthed (Fig. 1). The pace of the work on excavation of the amphitheatre and the requirements for efficient methods of gathering data influenced the experimental use of the photogrammetry in 2012, and it soon became part of the standard documentation practices on the entire site.

\section{METHODS OF GATHERING AND PROCESSING DATA}

Terrestrial and aerial photogrammetry, as two basic approaches of photogrammetry (Aber, Marzolff, Ries 2010: 23), were used during the excavation of the amphitheatre. Close range terrestrial imagery was used for documenting complex 


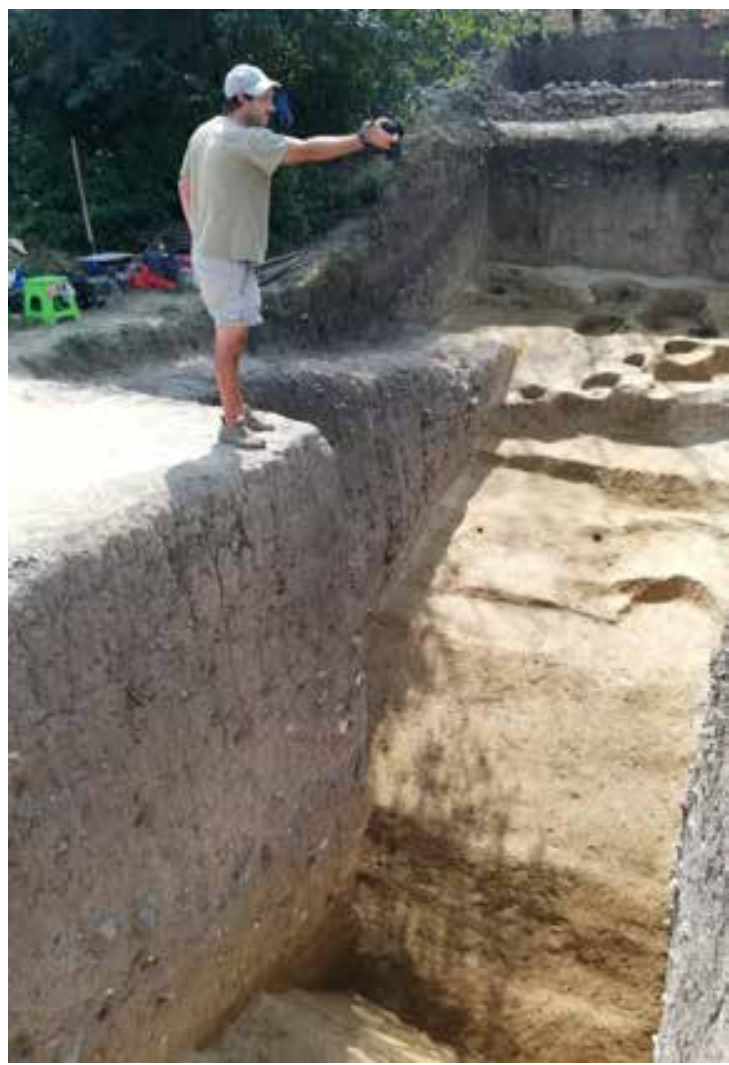

Fig. 2 Terrestrial photogrammetry (documentation of the Institute of Archaeology, Belgrade).

features, as well as for obtaining more detailed models. Aerial imagery, or rather unmanned aerial vehicle (UAV) photogrammetry ( $c f$. Eisenbeiß 2009: 2) was conducted over the wider areas with a large number of features. Regardless of the data gathering method, the workflow comprised two steps: in-field image collection and in-office data processing (Douglass et al. 2015: 140).

\section{In-field data gathering}

In-field data acquisition is executed by gathering a series of conventional images of the "scene", taken with digital cameras. For terrestrial measurements, we used NIKON D5000 and NIKON D5200 cameras with standard and wide-angle lenses (Fig. 2). A 2,55-3,00 m long monopod was also used for documenting less accessible features. The

5 The term "scene" as defined by M. Douglas, S. Lyn and M. Chodoronek (2015: 140) denotes the landscape, item, or a feature that is of interest to the archaeologist.
Phantom 3 professional drone ${ }^{6}$ was used for aerial imaging (Fig. 3). The UAV comes equipped with a SONY FC300X camera that has a maximal resolution of 12-megapixels. The quality and the resolution of the images directly influence the quality of the model and time of its creation. For this reason, all the cameras were set up in auto photography mode with an 8-megabyte resolution for aerial and 9-12-megabyte resolution for terrestrial imaging. All obtained images were in JPEG format, which proved optimal for later reviewing.

The recording was done in accordance with the advance of the excavation and the atmospheric conditions. As already determined, lighting was the most important factor for the quality of the model (Wallace 2016: 30). Ideally, photographing was done when the light was consistent, during overcast days or at dusk and dawn, because sunlight creates shadows of photographed multifaced features, which could potentially decrease the accuracy of the model. Although models created under high noon sunlight also proved adequate, direct sunlight was avoided whenever possible. Additionally, weather conditions that could endanger the stability of the aircraft, such as wind or rain, had to be taken into account when conducting aerial filming.

A few rules were devised in order to ensure a complete, highly detailed model and to eradicate the risk of user errors in the case of individual shots. The camera was moved in accordance with the photographed feature/scene. Optimally, consecutive photographs needed to have between 60 and $80 \%$ overlap, with each part of the scene visible on at least 3 images.

Georeferencing of the scene was done with the use of ground control points that were placed around the scene. Adequate choice of position and the precise measuring of these points is one of the

6 The drone has a maximal horizontal speed of $25 \mathrm{~m} / \mathrm{s}$ and a vertical speed of $5 \mathrm{~m} / \mathrm{s}$. The maximal distance between the operator and the drone is c. $500 \mathrm{~m}$ in an urban environment or up to $1 \mathrm{~km}$ in an open field. The drone is powered by two pairs of batteries, which enable it to stay in the air for approximately 15 minutes. 


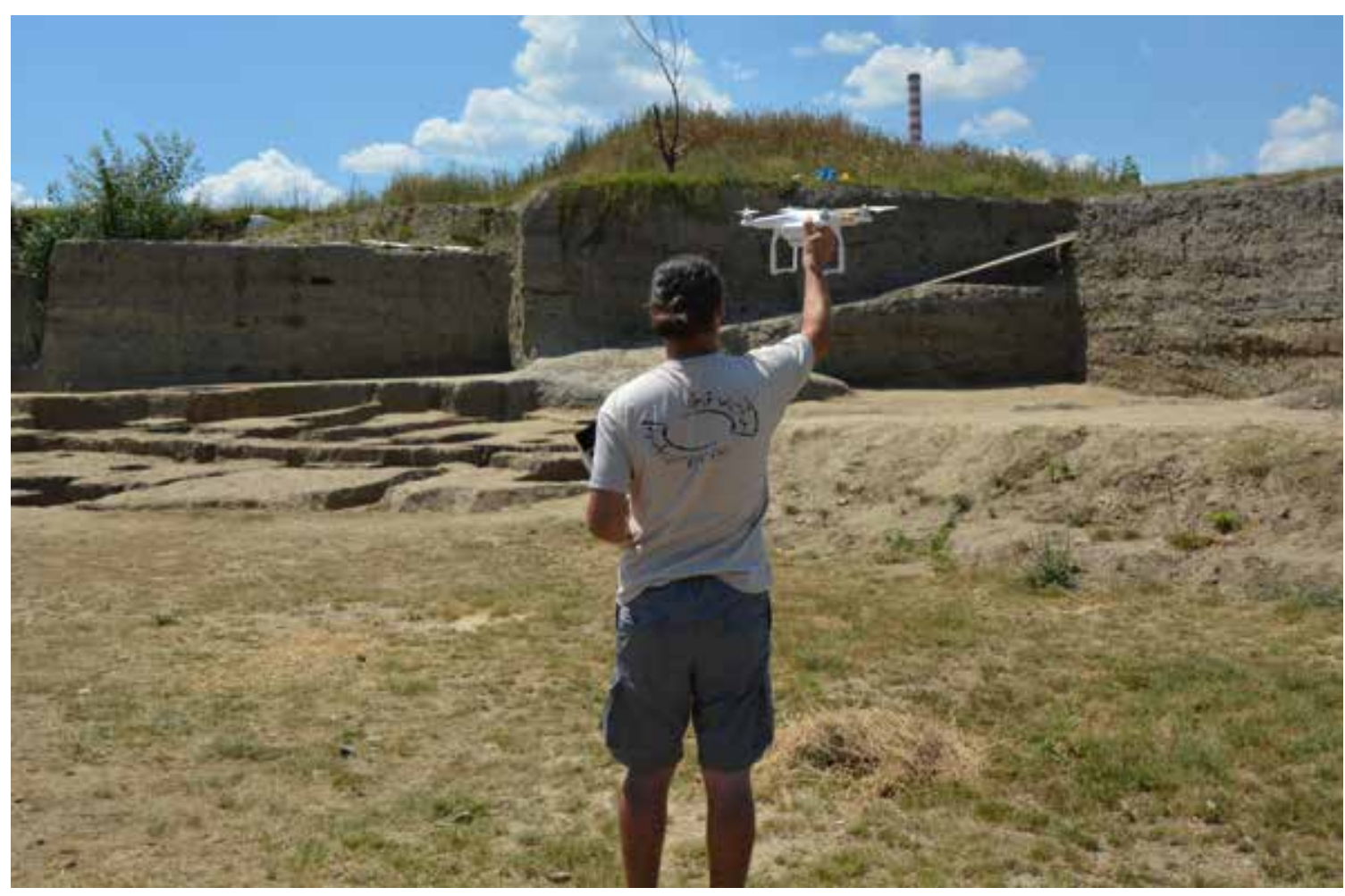

Fig. 3 Aerial photogrammetry (documentation of the Institute of Archaeology, Belgrade).

most important ways of improving the precision of the model itself. TRIMBLE GPS 5800 mobile rover, set on the real-time kinematic (RTK) method was used for measuring the points. A local GPS base station exists on the site, with the primary function of generating RTK corrections for mobile GPS rovers. Applying these corrections increases the precision of reference points to an error of just 1-3 cm. Exporting of absolute coordinates taken on the field is performed using the supporting software TRIMBLE GEOMATICS OFFICE (TGO 1.60).

\section{In-office data processing}

The second step in the creation of a model is in-office data processing. The process starts by choosing suitable photographs or rather removing the ones that are blurry or out of focus. Selected images are then imported into a 3D rendering and modeling software package AGISOFT PHOTOSCAN. The numerous advantages of this software suite has caused it to become one of the most popular programs used for the creation of models. ${ }^{7}$ It is characterized by user-friendliness, automated processes, high quality results, short rendering time, and great customization possibilities. Our experience has shown that the most useful options are automatic recognition of reference points and the possibility of their hand input for georeferenced models. The software offers the possibility of merging different models, as well as the creation of ortophotographs and DEM's which provide additional options for visualizing and analyzing data. Active customer support, as well as the existence of an up-to-date user forum, proved to be quite invaluable for solving technical issues and understanding the intricacies of the software.

The basis of digital photogrammetry methods are Structure from Motion (SfM) algorithms. ${ }^{8}$

\footnotetext{
7 For comparison of various photogrammetric and computer vision software $c f$. Verhoeven et al. 2015: 168-169, Table 2.

$8 \mathrm{SfM}$ algorithms allow simultaneous calculation of relative geometric projection and multiple $3 \mathrm{D}$ points from a series of overlapping images, taken with a camera orbited
} 

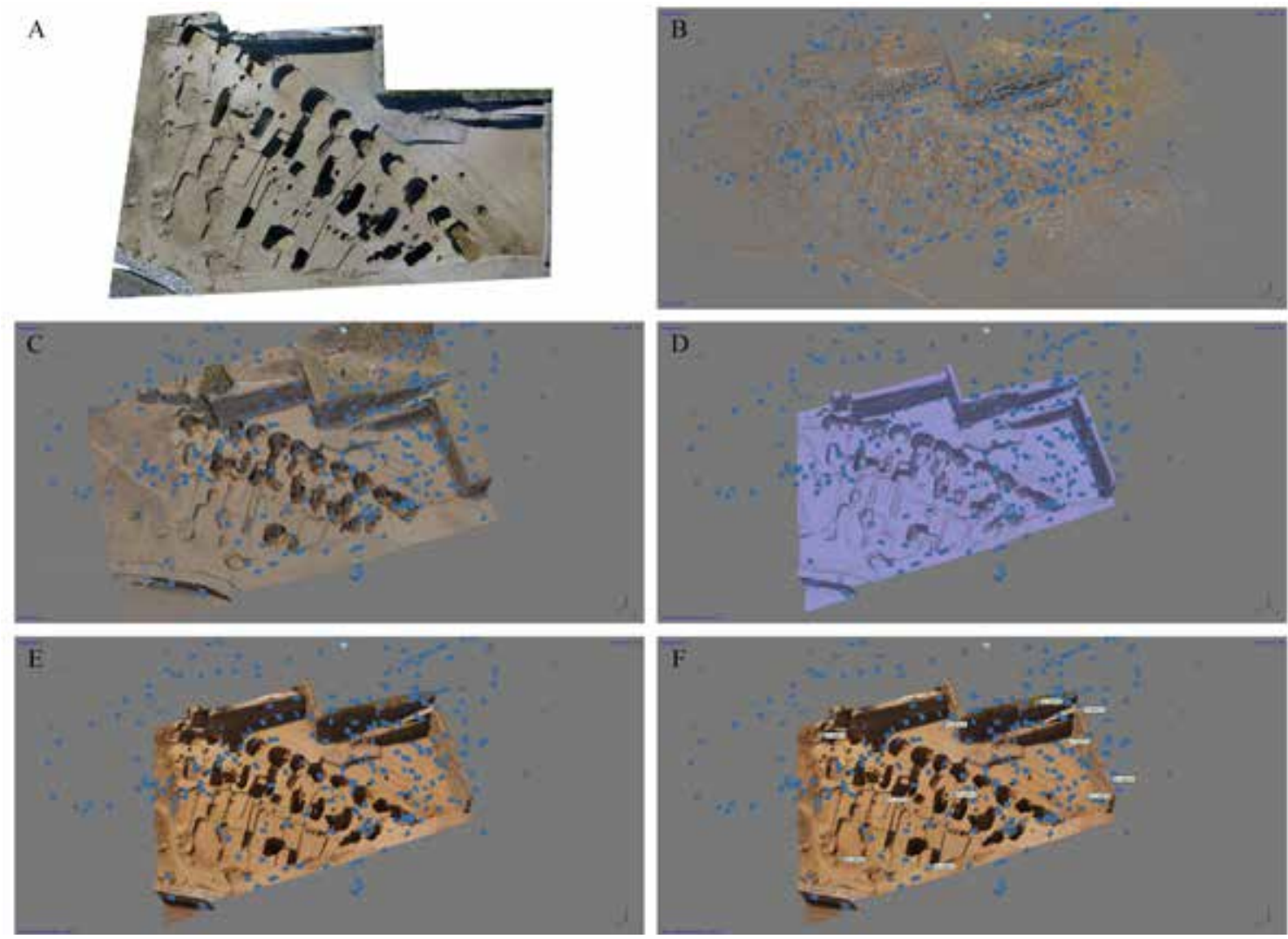

Fig. 4 Model creation: (A) Orthographic projection of the South-Western part of the grandstands (B) Sparse point cloud (C) Dense point cloud (D) Surface model (E) Textured surface model (F) Georeferencing of the model using control points (A-F: documentation of the Institute of Archaeology, Belgrade).

Based on a sequence of overlapping photographs, shot while moving the camera around the scene, these algorithms determine the geometric projection (scene geometry), i.e. reconstruct the position of the camera and the 3D geometry of the object. The software calculates the position of the photographs in space by aligning the randomly selected points from all the images. By detecting these characteristic points (such as object edges and specific details) on each photograph and tracking their position through multiple images, the software determines their location in a relative coordinate system (Douglass et al. 2015: 141; Verehofen et al. 2015: 167). Through this process, the position and orientation of the camera in a relative coordinate system is defined and a sparse point cloud is created (Douglass et al. 2015: 141) (Fig. 4).

The next step in the modelling process is the creation of a dense point cloud. This is done usaround the scene (Doneus et al. 2011: 82). ing the Multi-View Stereo (MVS) algorithms in relation to every point of the image, ${ }^{9}$ on a pixel by pixel basis (Verhoeven et al. 2015: 169; Wallace 2016: 38-39). Following the creation of a dense point cloud, the software creates a $3 \mathrm{D}$ polygon mesh. The mesh is created by connecting sets of corresponding vertices (points) within the point cloud, which form numerous triangular surfaces (faces), the sum of which forms a mesh (Douglass et al. 2015: 142; Wallace 2016: 39). Following the creation of the 3D mesh model, a texture is generated by projecting pixels from either all or selected photographs. The texture is then applied to the model, which is finished at this stage. Alternatively, a DEM can be used to place different textures that visualize different data instead of a photographic texture.

9 For each point it is possible to determine value, in radiometric data (intensity, grey value, color value), as well as geometrical data (position on the photograph). 


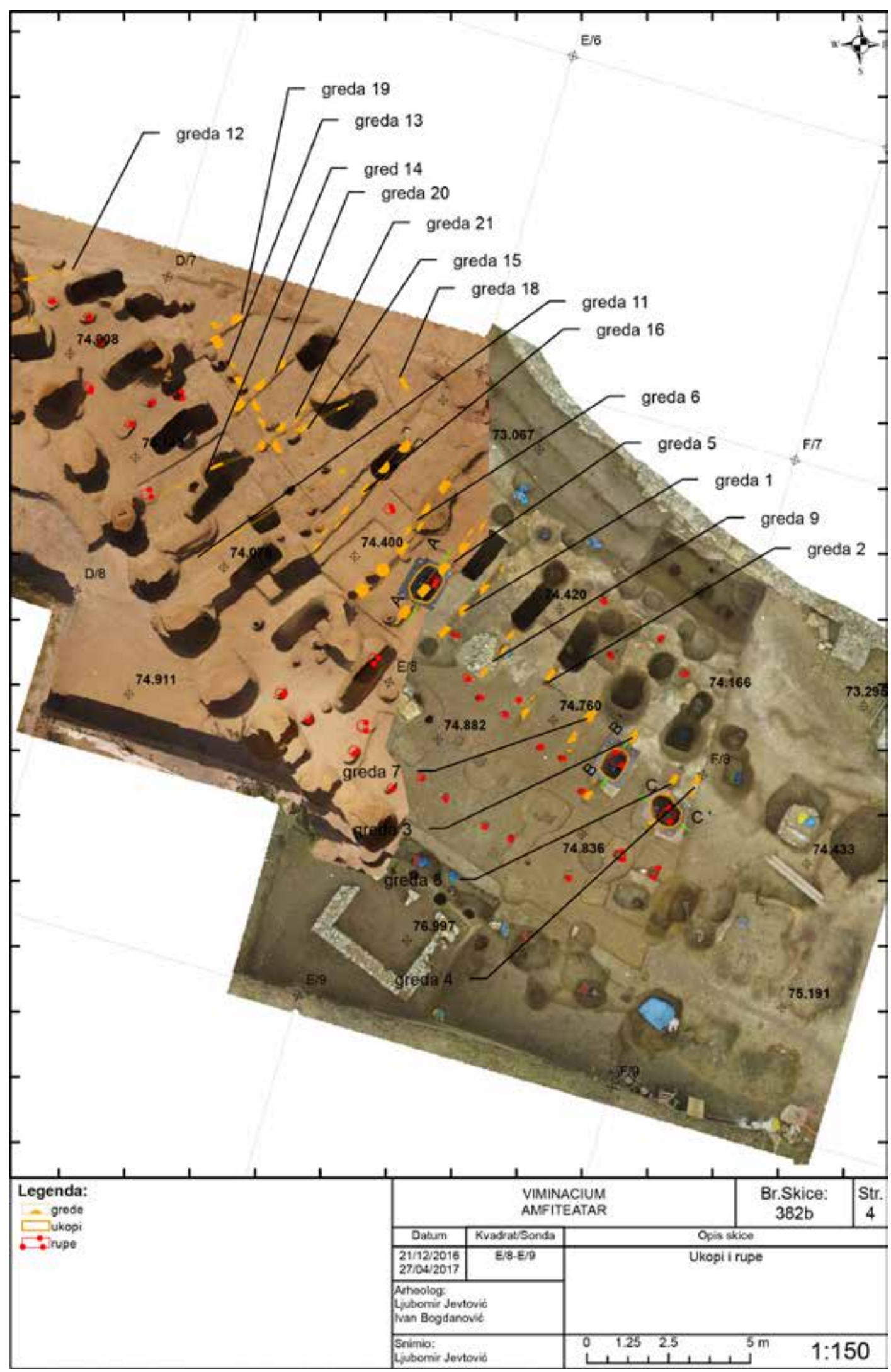

Fig. 5 Numerous pits with remains of wooden posts representing different construction phases of the amphitheatre (documentation of the Institute of Archaeology, Belgrade). 


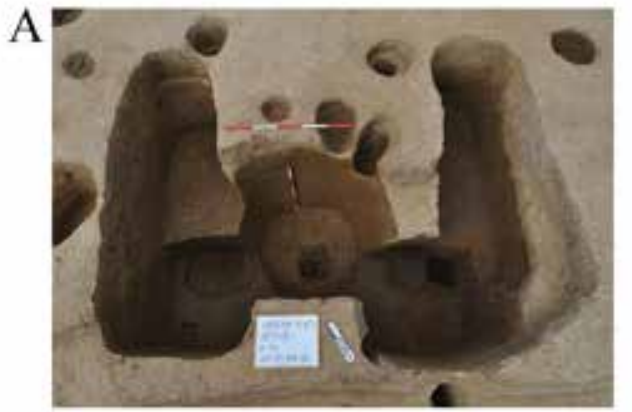

C

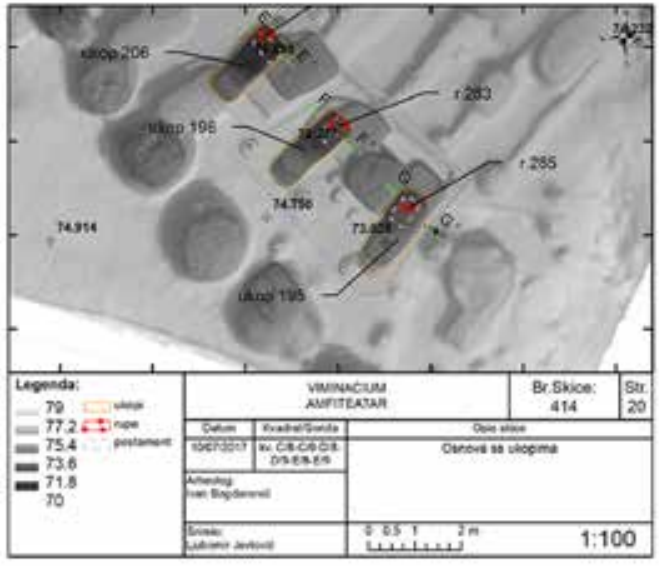

B

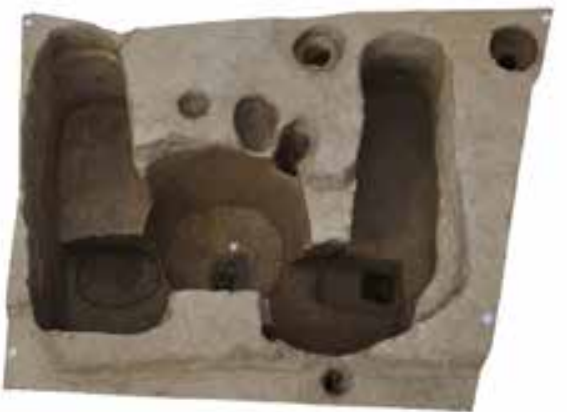

D

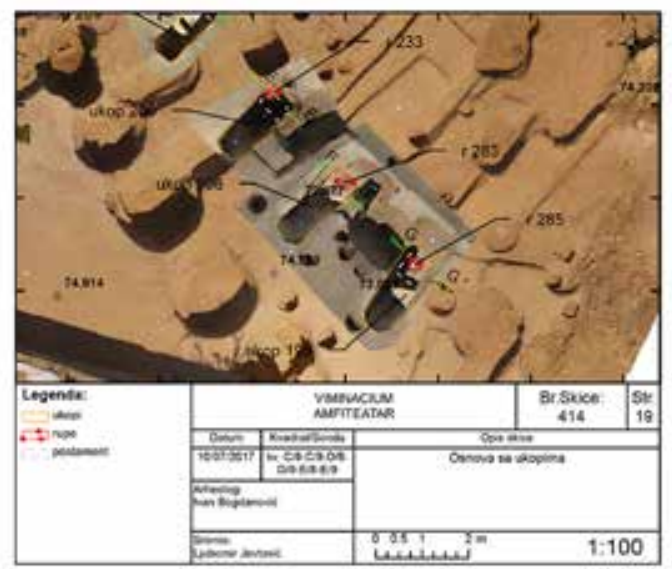

Fig. 6 A) Overlapping pits (B) Model of the pits (C) Technical drawing of the pits on the digital elevation model (D) Drawing and the model of the pits overlapped with the orthophoto of the South-Western grandstands of the amphitheatre (A-D: documentation of the Institute of Archaeology, Belgrade).

The final step of the process is the georeferencing of the model. This is done by adding markers in the position of the reference points and attributing coordinates to these points. Based on this, the model is rotated and scaled in order to fit into the absolute coordinate system. In case of major errors, optimization of the base point cloud is undertaken in regard to the coordinates of the reference points, and then the following steps are repeated (Doneus et al. 2011: 82-83).

\section{UTILIZATION OF THE PHOTOGRAMMETRIC DATA}

In archaeology, there are many options for 2D or $3 \mathrm{D}$ visualization of collected and processed photogrammetric data. Commonly, the creation of technical documentation is the most important step of the excavating process. During the early stages of the implementation in Viminacium, photogrammetry was used for the creation of traditional, in-situ documentation. It was perceived as a faster way of applying traditional techniques with the same end product. This opinion was shared by both archaeologists (since it allowed for a quicker continuation of fieldwork) and technicians (since it decreased their field time and exposure to the elements).

During the later phases of the excavation, including the investigation of the amphitheatre, it became obvious that visualization in $3 \mathrm{D}$ form is very advantageous and could be superior to standard 2D documentation. A greater quantity of information is obtained using 3D modeling then from drawings in $2 \mathrm{D}$. 


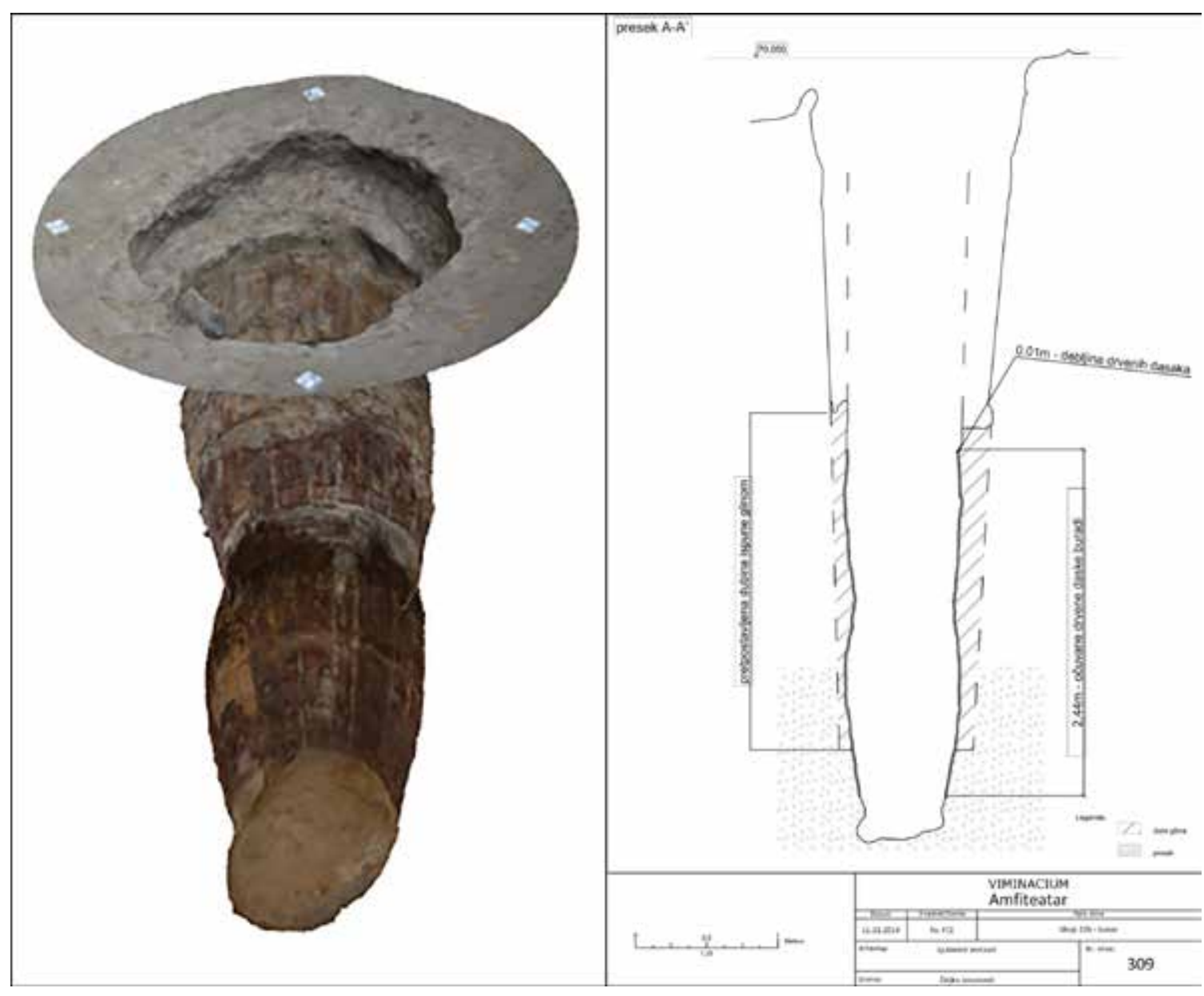

Fig. 7 (A) The model of the well (B) Technical drawing of the well derived from the model (A-B: documentation of the Institute of Archaeology, Belgrade).

\section{Technical documentation}

The photogrammetry was integrated smoothly into the standard documenting techniques of unearthed features on the Viminacium amphitheatre as well as on other locations. AGISOFT PHOTOSCAN has a built-in orthophoto option which allows easy extraction of the accurate $2 \mathrm{D}$ portrayal of the model. This portrayal would be imported into the AUTOCAD software ${ }^{10}$ and used as a basis for technical drawings of standard, albeit digitalized maps, plans, and field sketches.

Immediately, a few benefits of the photogrammetric modeling were observed. The accuracy of documented features increased significantly,

10 Alternatively, any of numerous software options, used for precision drawing, could be used instead of the mentioned software. as it became less dependent on the experience of the staff and thus less prone to human errors. Major factors such as insufficient field recording time, inconsistencies, and subjective perspectives during the recording process, become irrelevant, as the process is both time-efficient and objective. The technique of gathering data and the digitalized form of the process meant that the size of the feature was not crucial anymore, as the scale of the recorded scene can be easily modified for final documentation and publications.

Another important advantage of the method is that it allowed obtaining information about features that were difficult to document using traditional methods. Photogrammetry proved distinctly superior for documenting complicated 


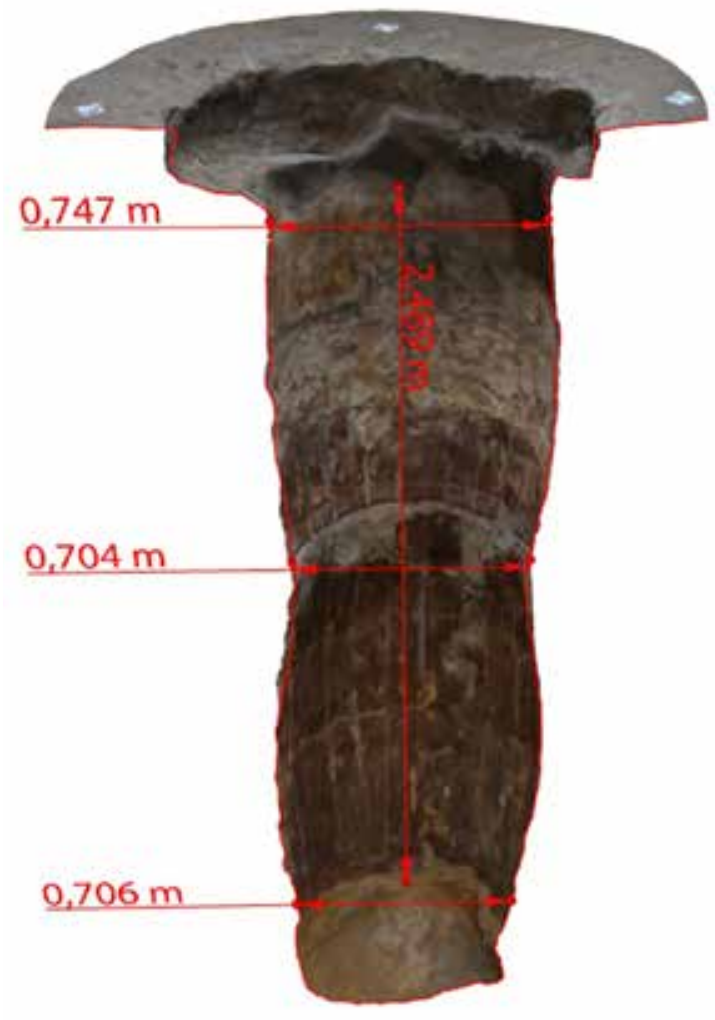

Fig. 8 Model of a lower part of the well in a PDF format, cross section and the measurements (documentation of the Institute of Archaeology, Belgrade).

archaeological situations. The mentioned method was much easier and more accurate in documenting features, especially their cross-sections, which was significantly faster.

During the excavations of the amphitheatre, it was possible to conclude that surviving parts of the grandstands (cavea) were represented by pits with postholes or lower parts of the wooden posts that supported rows of seats (Bogdanović 2019: 180-186, 263-265; Nikolić, Bogdanović 2015: 553). The existence of several overlapping pits and posts in every single part of the space covered by the cavea indicates different phases of the construction of the building (Fig. 5). For these reasons, documenting just one of these features was demanding, while the presence of a vast number of pits and posts made the problem exponentially greater. The aerial photogrammetry provided an easy way of simultaneous documenting of a large number of these features, while the terrestrial method allowed for fast creation of precise and detailed models when occasions demanded (Fig. 6). Combining both methods allowed us to gain all the needed information about the traces of wooden construction of the amphitheatre, which allowed easier recognition of the different phases of the construction of the cavea.

Nevertheless, the nature of some structures or some of their elements (underground structures), their accessibility (tight spaces or covered by some other feature), or some other factor (the lack of natural light) can affect photogrammetry. However, the method was far less affected by the mentioned limitations than traditional methods. The most prominent examples of the usefulness of the technique during the excavation of the amphitheatre were photogrammetric surveys of the well (Nikolić, Jevtović, Stojić 2017: 94-95; Bogdanović 2016: 13-14) and water collector (Bogdanović 2019: 196). The major of the above-mentioned problems was the fact that these features are narrow and have depths of c. $5 \mathrm{~m}$ and c. $2.5 \mathrm{~m}$, which made even basic tape measurements difficult. Following the principles of methodology and the safety regulations, the excavation of the well was conducted in phases, while recording of the collector was done using a tripod. Thus, a model of the well was created for each subsequent phase of the excavation. Individual models were later merged into a single model, representing the entire feature. This allowed for obtaining of a profile map with planar and cross-section perspectives showing every detail of the feature (Fig. 7).

\section{$3 D$ Visualization and presentation}

The results of the photogrammetry could be visualized in many ways, depending on the expected results and their intended purpose. AGISOFT PHOTOSCAN allows the possibility to export a point cloud in any phase of the modeling, a completed model, an orthophoto, or a DEM. Any of these options has its benefits, yet for regular examination of the excavated features, the finished, 
fully texturized model was the most obvious and usually the best choice. As the models are digitalized representations of the excavated (and thus often destroyed) feature, they are ideally suited for digital archiving and further analysis and examination following fieldwork. Additionally, they can be applied in a wide variety of studies, ranging from the research of a single artefact to an entire landscape.

Models can be exported in various digital formats (pdf, obj, dxf, 3ds, wrl, dae, ply, u3). We used a PDF format as it has already proved to be the most advantageous, due to its versatility and ease of sharing. This file format is common and thus easily accessible. Additionally, although decreased in size, PDF models retain much of their detail while the file size is low, which allows for easy sharing. Exporting in other formats, such as OBJ, can be advantageous since the model retains all its detail, but we realized that the downside is that it requires additional software packages to open. Luckily, most of these packages are open source, such as MESHLAB.

Another option that the AGISOFT PHOTOSCAN allows is the online posting of 3D models. It is possible to do using a number of web services (online 3D file-sharing platforms such as SKETCHFAB) that can present a fast and easily accessible option for private and public display.

There are several advantages of the models over 2D documentation. During the excavation process, they were useful for examining the features and structures. In later phases, during analysis of the excavated features, they allowed reexamining of the results. Finally, the models can be both analytical and appealing for the publication and presentation of results. 3D models can be rotated, which allows for their viewing from any angle. They can be cross-sectioned across any plane, which allows much easier study of their internal structure. As the models are fully scaled, they can be used for the extraction of accurate metric information, such as dimensions or volume. If the model is georeferenced, $\mathrm{x}, \mathrm{y}$ or $\mathrm{z}$ coordinates of a single point within the model can be obtained. All of the mentioned operations can be achieved with unparalleled precision, depending solely on the skill of the user (Fig. 8). Additionally, as they are related to photography, fully texturized models offer a great visual representation of features.

A georeferenced orthophoto of a model can be inserted into any Geographic information system (GIS) software. This allowed us further analysis of obtained data but also overlapping with other data, obtained by prospection (aerial photography, satellite imagery, results of geophysical research, etc.), as well as from plans and other archaeological documentation. Such bases have become a cornerstone of spatial research in the past couple of decades and already exist for most archaeological sites in other countries. Photogrammetric models are compatible with such datasets and have proved to be a valuable addition for various spatial analysis.

The visual and metric quality of the models makes them a convenient and versatile option for presenting results to both professional and public audiences. Displaying the model as an image or in a video format is appropriate for basic analysis, dissemination and presentation of excavated data. The insights obtained in such a way have proved crucial during the conservation and reconstruction of certain parts of the amphitheatre. Additionally, we used the same formats for presenting the results of the excavation (Fig. 9). They are appropriate for a variety of purposes, ranging from reports demanded by public institutions, to the presentation of our achievements in scientific lectures. This modern approach significantly enhanced the visualization of archaeological discoveries, by making it more appealing, while simultaneously allowing the observers an easier understanding of a certain situation.

Displaying the results of photogrammetry is very advantageous for commercial purposes. It can be used for presenting Viminacium and the results of our excavations in the media. Also, it can be used to enrich the information on certain structures and features within the archaeological park. Inclusion of modern interactive approaches 
could be crucial for future promotions of the site. In perspective, it can enhance the visitor's experience, which will hopefully increase the number of guests and thus further the development of the archaeological park.

\section{CONCLUSION}

The current benefits and enormous potential of photogrammetry make it a worthwhile addition to standard archaeological practices. It provides a new insight for studies of archaeological sites, landscapes and features, but also for small finds and other materials, as it has already proved quite invaluable for other disciplines that deal with cultural heritage.

During the investigation of the amphitheatre, we realized that photogrammetry represents a significant addition to the excavation process on Viminacium. Gained experience showed us that this method is extremely useful in the creation of archaeological documentation, as well as for the visualization and presentation of cultural heritage.

The primary characteristic of photogrammetry is the simplicity of data acquisition since the creation of the model requires only clear photographs and a few georeferenced points. The field preparation is standard, as for any documentation technique, and the perquisites are minimal. The process requires standard equipment, regularly used during fieldwork, such as utility-grade cameras and computers as well as a way of georeferencing the points. For terrestrial photogrammetry, in-field data gathering does not require any specialized training, except for a basic knowledge of photography and the following of some basic rules. Aerial photogrammetry does require specialized equipment and training in operating UAV's, but our experience has shown that regular and affordable UAV's offer more than decent results, while the training is relatively simple. The method is time efficient and compared to other traditional methods (drawing/sketching) signifi- cantly faster. It is easily incorporated into existing field procedures and allows an additional benefit that the fieldwork can proceed while data processing and analysis is still under way.

The second stage of the process, i.e. model creation, is straightforward and automatized. It requires only basic technical skills and knowledge of the program. The obtained 3D model is geometrically precise, positioned in the georeferenced system, and provides photo-realistic visualization of the archaeological feature in 3D. Based on the model it is possible to create standard documentation of far greater precision than that of traditional sketch drawing. Other output formats provide additional benefits of easy manipulation and distribution. These can be used for professional as well as public visualization. Mentioned formats also offer a possibility of much realistic reexamining of the excavated features and can be easily complemented with other forms of documentation, which can often provide additional details.

The analytical quality and visual appeal of photogrammetry can be used with great effect for visual presentations, in both academic as well as in public displays. Its potential and value lie in interactive visualization and multimedia exhibitions that can be used to increase public awareness and provide additional understanding and appreciation of cultural heritage.

Our recent work undoubtedly suggests that photogrammetry should be a necessary addition for upcoming archaeological campaigns. Also, modern photogrammetry is finding new uses that will allow the exploration of new horizons, as it has become one of the driving forces for future advancements in the field of archaeology.

\section{BIBLIOGRAPHY}

\author{
Aber, J. S., Marzolff, I. and Ries, J. B. 2010 \\ Small-Format Aerial Photography and UAS Im- \\ agery: Principles, Techniques and Geoscience \\ Applications, Amsterdam: Elsevier Science.
}




\section{Bogdanović, A. 2016}

Rimski bunari na Viminacijumu, Master rad, Filozofski fakultet, Univerzitet u Beogradu.

\section{Bogdanović, I. 2019}

Izgradnja rimskog amfiteatra na primeru Viminacijuma, Doktorski rad, Filozofski fakultet, Univerzitet $\mathrm{u}$ Beogradu.

Богдановић, И., Рогић, Д. и ВуковићБогдановић, С. 2018

Виминацијумски амфитеатар, Римски лимес и градови на тлу Србије, (ур.) М. Кораћ, С. Поп-Лазић, Београд: Српска академија наука и уметности, Археолошки институт, 44-49. (Bogdanović, I., Rogić, D. i Vuković-Bogdanović, S. 2018

The amphitheatre of Viminacium, Roman limes and the cities in the territory of Serbia, (eds.) M. Korać, S. Pop-Lazić, Belgrade: Serbian Academy of Sciences and Arts, Archaeological institute, 44-49).

\section{Бугарски, И. и Иванишевић, В. 2014}

Примена аерофотографије у српској археологији, Саопштења XLVI: 251-263.

(Bugarski, I. i Ivanišević, V. 2014

Primena aerofotografije u srpskoj arheologiji, $S a$ opštenja XLVI: 251-263).

\section{Cantoro, G. 2015}

Aerial photogrammetry: when archaeology meets SIFT, Recovering Lost Landscapes, (eds.) V. Ivanišević, T. Veljanovski, D. C. Cowley, G. Kiarszys and I. Bugarski, Belgrade: Institute of archaeology, 117-128.

Doneus, M., Verhoeven, G., Fera, M., Briese, C., Kucera, M. and Neubauer, W. 2011

From deposit to point cloud - A study of low-cost computer vision approaches for the straightforward documentation of archeological excavations. Geoinformatics FCE CTU 6: 81-88.
Douglass, M., Lin, S. and Chodoronek, M. 2015

The Application of 3D Photogrammetry for In-Field Documentation of Archaeological Features, $A d$ vances in Archaeological Practice 3 (2): 136-152.

\section{Eisenbeiß, H. 2009}

UAV Photogrammetry, Zurich: Institut für Geodäsie und Photogrammetrie Eidgenössische Technische Hochschule Zürich.

\section{Иванишевић, В. и Бугарски, И. 2015}

Дигитална фотограметријска снимања античких и средњевековних локалитета у Србији, Саопштена XLVII: 165-180.

(Ivanišević, V. i Bugarski, I. 2015

Digitalna fotogrametrijska snimanja antičkih i srednjevekovnih lokaliteta u Srbiji, Saopštenja XLVII: 165-180).

Иванишевић, В., Бугарски, И. и Булатовић, A. 2015

Фотограметријско снимање налазишта Бубањ, Гласник друштва конзерватора Србије, 39: 53-57.

(Ivanišević, V., Bugarski, I. i Bulatović, A. 2015

Fotogrametrijsko snimanje nalazišta Bubanj, Glasnik društva konzervatova Srbije 39: 53-57).

Иванишевић, В., Стаменковић, А. и Јовановић, С. 2017

Примена дигиталне археологије у заштитним истраживањима: пример Мале Копашнице, Cаопштеља IL: 229-249.

(Ivanišević, V., Stamenković, A. i Jovanović, S. 2017

Primena digitalne arheologije u zaštitnim istraživanjima: primer Male Kopašnice, Saopštenja IL: 229-249).

Karović, G., Mihajlović, D. and Vučković, D. 2008

Trajan's bridge over the Danube. The current results of underwater archaeological research, Proceedings of the 13th Annual Meeting of the European Asso- 
ciation of Archaeologists (Zadar, Croatia, 18-23

September 2007): Session: Underwater archaeology, (eds.) I. Radić Rossi, A. Gaspari and A. Pydin, Zagreb: Hrvatsko arheološko društvo, 281-289.

\section{Korać, M., Pavlović, R. i Mrđić, N. 2006}

Viminacijum - daljinska detekcija i GIS, Arheologija i prirodne nauke 1 (2005): 21-26.

\section{Krauss, K. 2007}

Photogrammetry, Geometry from Images and Laser Scans, second edition, (Trans. by

Ian Harley and Stephen Kyle), Berlin-New York: Walter de Gruyter Berlin New York.

Linder, W. 2003

Digital Photogrammetry: Theory and Applications, Berlin Heidelberg: Springer-Verlag Berlin Heidelberg.

Linder, W. 2009

Digital Photogrammetry: A practical course, Berlin Heidelberg: Springer-Verlag Berlin Heidelberg.

Luhmann, T., Robson, S., Kyle, S. and Harley, I. 2011

Close Range Photogrammetry: Principles, Techniques and Applications, Dunbeath: Whittles Publishing.

McGlone, J. C., Mikhail, E. M., Bethel, J. S., Photogrammetry, A. S. F., Sensing, R. and Mullen, R. 2004

Manual of Photogrammetry, Bethesda: American Society for Photogrammetry and Remote Sensing.

Nikolić, S. and Bogdanović, I. 2015

Recent Excavations on the Amphitheatre of Viminacium (Upper Moesia), Proceedings of the 22nd International Congress of Roman Frontier Studies, Ruse, Bulgaria, September 2012, (eds.) L. Vagalinski and N. Sharankov, Sofia: National Archaeological Institute with Museum Bulgarian Academy of Sciences, 547-555.
Nikolić, S., Jevtović, Lj. i Stojić, G. 2017

Arheološka istraživanja prostora viminacijumskog amfiteatra u 2014. godini, Arheologija u Srbiji, projekti Arheološkog instituta u 2014. godini, (eds.) I. Bugarski, N. Gavrilović Vitas i V. Filipović, Beograd: Arheološki institut, 93-98.

\section{Schenk, T. 2005}

Introduction to Photogrammetry, Columbus: Department of Civil and Environmental Engineering and Geodetic Science: The Ohio State University.

\section{Verhoeven, G. and Docter, R. 2013}

The Amphitheatre of Carnuntum - towards a complete 3D model using airborne structure from motion and dense image matching, Archaeological prospection - Proceedings of the 10th International Conference on Archeological Prospection (Vienna May 29th - June 2nd 2013), (eds.) W. Neubauer, I. Trinks, R. B. Salisbury and C. Einwögerer, Vienna: Austrian Academy of Sciences, $438-440$.

Verhoeven, G., Doneus, N., Doneus, M. and Štuhec, S. 2015

From pixel to mesh: accurate and straightforward 3D documentation of cultural heritage from the Cres/Lošinj archipelago (rezime: Od piksela do mreže - precizno i jednostavno 3d dokumentiranje kulturne baštine cresko-lošinjskog arhipelaga), Istraživanja na otocima - Izdanja hrvatskog arheološkog društva Svezak 30, (eds.) Z. Ettinger Starčić and D. Tončinić, Zagreb: Hrvatsko arheološko društvo i Lošinjski muzej, 165-176.

\section{Wallace, C. 2016}

Photogrammetry in Mediterranean Archaeology, Master's Thesis, University of Waterloo. (http:// hdl.handle.net/10012/10344) 


\section{REZIME}

AMFITEATAR U SLIKAMA PRIMENA FOTOGRAMETRIJE U ISTRAŽIVANJIMA VIMINACIJUMSKOG AMFITEATRA

KLJUČNE REČI: VIMINACIUM, AMFITEATAR, FOTOGRAMETRIJA, 3D MODELOVANJE, METODOLOGIJA ARHEOLOŠKIH ISTRǍ̌IVANJA.

Fotogrametrijski metod predstavlja novinu u izradi arheološke dokumentacije. Iako je nastao sredinom XIX veka, do njegove značajnije upotrebe $u$ arheologiji dolazi tek sa razvojem digitalne fotogrametrije tokom poslednjih decenija.

U istraživanjima Viminacijuma, fotogrametrija je eksperimentalno primenjena 2012. godine prilikom iskopavanja amfiteatra. Uočene prednosti učinile su da navedeni metod postane standard u izradi dokumentacije na ovom lokalitetu.

U radu je prikazano naše iskustvo sa upotrebom fotogrametrije u istraživanjima amfiteatra, odnosno, prednosti i mane ovog metoda, kao i moguća upotreba u prezentaciji kulturnog nasleđa. Čitav proces dokumentovanja arheoloških celina činili su prikupljanje podataka i njihova dalja obrada.

Fotogrametrija se pokazala kao veoma pogodna za izradu tradicionalne 2D dokumentacije. Ovaj metod je znatno brži i objektivniji od tradicionalnih metoda, a omogućio je izradu detaljne i precizne dokumentacije čak i kod izrazito komplikovanih arheoloških celina, nezavisno od njihove veličine i veštine crtača. Rezultati snimanja predstavljeni su u okviru 3D modela. Oni nude niz prednosti u arhiviranju podataka i pri njihovoj analizi, a budući da su zasnovani na fotografijama, modeli sa teksturom su odlična opcija za vizualnu predstavu otkrivenih celina.

Predstavljanje modela u obliku slika ili u video formatu, može se koristiti u prezentovanju istraženih celina i rezultata arheoloških iskopavanja, u naučne ili komercijalne svrhe. Na ovaj način fotogrametrija se čini veoma korisnom, jer omo- gućava vizuelizaciju kulturnog nasleđa, čineći ga vizuelno dopadljivim, ali i lakšim za razumevanje.

$$
* * *
$$

Arheologija i prirodne nauke (Archaeology and Science) is an Open Access Journal. All articles can be downloaded free of charge and used in accordance with the licence Creative Commons - Attribution-NonCommercial-NoDerivs 3.0 Serbia (https://creativecommons.org/licenses/ by-nc-nd/3.0/rs/.

Časopis Arheologija i prirodne nauke je dostupan u režimu otvorenog pristupa. Članci objavljeni u časopisu mogu se besplatno preuzeti sa sajta i koristiti u skladu sa licencom Creative Commons - Autorstvo-Nekomercijalno-Bez prerada 3.0 Srbija (https://creativecommons.org/ licenses/by-nc-nd/3.0/rs/. 